Original Article

\title{
Decrease of PKB/Akt Phosphorylation is Partially Mediated by SAPK/JNK Activation in Serum-free L6 Myoblasts Starved with Low Glucose
}

\author{
Mee-Young Kim, PT, PhD ${ }^{1) a}$, Jeong-Uk Lee, PT, PhD ${ }^{1) a}$, Ju-Hyun Kim, PT, PhD ${ }^{1)}$, \\ Lim-Kyu Lee, PT, MS ${ }^{1)}$, Seung-Min Yang, PT, $\mathrm{MS}^{1)}$, Byoung-Sun Park PT, MS ${ }^{1)}$, \\ Hye-Joo Jeon, PT, MS ${ }^{1)}$, Won-Deok Lee, PT, MS ${ }^{1)}$, Ji-Woong Noh, PT, MS ${ }^{1)}$ \\ Taek-Yong Kwak, PhD ${ }^{2)}$, Sung-Ho Jang, PhD ${ }^{3)}$, Tae-Hyun Lee, PhD ${ }^{4)}$, Ju-Young Kim, PhD ${ }^{4}$, \\ BOKYUNG KIM, DVM, PhD ${ }^{5)}$, JunghwAN KIM, PT, $\mathrm{PhD}^{6)^{*}}$ \\ 1) Laboratory of Health Science and Nanophysiotherapy, Department of Physical Therapy, Graduate \\ School, Yongin University, Republic of Korea \\ 2) Department of Taekwondo Instructor Education, College of Martial Arts, Yongin University, \\ Republic of Korea \\ 3) Department of Judo, College of Martial Arts, Yongin University, Republic of Korea \\ 4) Combative Martial Arts Training, College of Martial Arts, Yongin University, Republic of Korea \\ 5) Institute of Functional Genomics, Department of Physiology, School of Medicine, Konkuk University, \\ Republic of Korea \\ 6) Department of Physical Therapy, College of Public Health and Welfare, Yongin University: Yongin \\ 449-714, Republic of Korea
}

\begin{abstract}
Purpose] Studies have been using cell cultures of muscle cells to mimic atrophy in in vivo and in vitro tests. However, changes in the activation of atrophy-related PKB/Akt is not fully understood in serum-free starved skeletal muscle cells. The purpose of the present study was to determine the change of PKB/Akt phosphorylation in L6 myoblasts under serum-free starvation conditions. [Methods] We used western blotting to examine PKB/Akt expression and phosphorylation in atrophied L6 myoblasts. [Results] The phosphorylation of PKB/Akt was significantly lower in L6 myoblasts under serum-free starvation than that of the control group. Serum-free starvation for $6,12,24,36,48,72,96$, and 120 hours significantly decreased the phosphorylation of PKB/Akt. Furthermore, the decrease of PKB/Akt phosphorylation under serum-free starvation was partially restored by SP600125, an inhibitor of SAPK/JNK. [Conclusion] These results suggest that decrease of PKB/Akt phosphorylation due to serum-free starvation with low glucose is partially related to the activity of SAPK/JNK in L6 myoblasts.

Key words: PKB/Akt, Serum-free starvation, L6 myoblasts
\end{abstract}

(This article was submitted Apr. 2, 2014, and was accepted May 16, 2014)

\section{INTRODUCTION}

Akt, also called protein kinase $\mathrm{B}(\mathrm{PKB} / \mathrm{Akt})$, is a pleckstrin homology domain-containing serine/threonine kinase which is activated by various stimuli, such as growth factors and agonists ${ }^{1-4)}$. Akt has also been widely reported to have key roles in muscle hypertrophy and the prevention of atrophy ${ }^{1,3,5)}$. Our previous study demonstrated that the phosphorylation of $\mathrm{PKB} / \mathrm{Akt}$ in atrophied muscle tissues significantly diminishes in a time-dependent manner in

${ }^{a}$ The first 2 authors (Kim MY and Lee JU) contributed equally to this work.

*Corresponding author. Junghwan Kim (E-mail:

junghwankim3@yongin.ac.kr)

(C2014 The Society of Physical Therapy Science. Published by IPEC Inc.

This is an open-access article distributed under the terms of the Cre-

ative Commons Attribution Non-Commercial No Derivatives (by-ncnd) License $<$ http://creativecommons.org/licenses/by-nc-nd/3.0/>. cast-immobilized rats ${ }^{1)}$. Starvation in culture induces loss of muscle mass ${ }^{6-8)}$. To study the signal transduction of atrophy, various cell culture models have been developed ${ }^{9-12)}$. The elevated degradation of proteins in skeletal muscle atrophy and serum-free starvation is coupled with the activation of atrophy markers such as muscle-specific RING finger-1 (MuRF-1) and the muscle atrophy F-box protein (MAFbx, also called atrogin-1), and these are greatly upregulated in the initiation and development of skeletal muscle atrophy ${ }^{6-8)}$. However, changes in the phosphorylation of PKB/Akt in starvation-induced atrophy and its temporal characteristics are not fully understood. Therefore, we investigated the changes in the phosphorylation of $\mathrm{PKB} / \mathrm{Akt}$ in L6 myoblasts grown under serum-free starvation conditions with low glucose.

\section{MATERIALS AND METHODS}

The L6 myoblasts were purchased from the American 
1758 J. Phys. Ther. Sci. Vol. 26, No. 11, 2014

Table 1. Changes in the expression and phosphorylation of PKB/Akt in L6 myoblasts grown under serum-free starvation with low glucose

\begin{tabular}{|c|c|c|c|c|c|}
\hline $\begin{array}{l}\text { Experimental } \\
\text { period }\end{array}$ & $\begin{array}{c}\text { PKB/Akt } \\
(\%)\end{array}$ & $\begin{array}{c}\mathrm{p}-\mathrm{PKB} / \mathrm{Akt} \\
(\%)\end{array}$ & Variable & $\begin{array}{c}\text { PKB/Akt } \\
(\%)\end{array}$ & $\begin{array}{c}\mathrm{p}-\mathrm{PKB} / \mathrm{Akt} \\
(\%)\end{array}$ \\
\hline 0 hour & $100.0 \pm 0.0$ & $100.0 \pm 0.0$ & $\mathrm{HG}+10 \% \mathrm{FBS}$ & $100.0 \pm 0.0$ & $100.0 \pm 0.0$ \\
\hline 6 hours & $100.7 \pm 4.1$ & $18.7 \pm 6.6^{*}$ & $\mathrm{LG}+2 \% \mathrm{FBS}$ & $99.3 \pm 1.8$ & $89.3 \pm 8.4$ \\
\hline 12 hours & $99.3 \pm 1.2$ & $11.3 \pm 4.5^{*}$ & $\mathrm{LG}+0 \% \mathrm{FBS}$ & $98.7 \pm 0.9$ & $7.7 \pm 2.4^{*}$ \\
\hline 24 hours & $98.7 \pm 2.6$ & $10.3 \pm 3.5^{*}$ & $\mathrm{HG}+10 \% \mathrm{FBS}$ & $100.0 \pm 0.0$ & $100.0 \pm 0.0$ \\
\hline 36 hours & $101.0 \pm 4.9$ & $10.7 \pm 3.8^{*}$ & $\mathrm{LG}+0 \% \mathrm{FBS}$ & $103.3 \pm 5.8$ & $5.7 \pm 2.9^{*}$ \\
\hline 48 hours & $99.3 \pm 3.5$ & $13.3 \pm 4.3^{*}$ & $\mathrm{SB} 20358010 \mu \mathrm{M}$ & $102.7 \pm 2.3$ & $7.0 \pm 3.8^{*}$ \\
\hline 72 hours & $100.7 \pm 5.8$ & $11.3 \pm 4.1^{*}$ & SP600125 $10 \mu \mathrm{M}$ & $102.3 \pm 2.4$ & $69.7 \pm 7.9 *$ \\
\hline 96 hours & $101.0 \pm 3.5$ & $10.3 \pm 6.0^{*}$ & LY294002 $10 \mu \mathrm{M}$ & $103.3 \pm 2.3$ & $4.3 \pm 2.4^{*}$ \\
\hline 120 hours & $102.3 \pm 4.1$ & $10.7 \pm 5.9 *$ & & & \\
\hline
\end{tabular}

Data are presented as the mean \pm SEM. HG, glucose of high concentration; LG, glucose of low concentration; $p$, phosphorylated protein; PKB/Akt, protein kinase B/Akt; SB203580, an inhibitor of p38MAPK; SP600125, an inhibitor of SAPK/JNK; LY294002, an inhibitor of phosphatidylinositol 3-kinase. The basal levels of abundance and phosphorylation in the control ( 0 hour) were considered to be $100 \%$. *: vs. 0 hour control, $\mathrm{p}<0.05$

Type Culture Collection (Rockville, MD, USA) and cultured in Dulbecco's modified Eagle's medium containing $10 \%$ fetal bovine serum (FBS), $100 \mathrm{U} / \mathrm{ml}$ penicillin, $100 \mu \mathrm{g} /$ $\mathrm{ml}$ streptomycin, $200 \mathrm{mM}$ glutamine and 4,500 $\mathrm{mg} / \mathrm{L} \mathrm{D}$ glucose (high concentration). To induce serum-free starvation, groups of cells were grown to $60-70 \%$ confluence with undernourishment in DMEM containing $1,000 \mathrm{mg} / \mathrm{L}$ D-glucose (low concentration) without FBS for $6,12,24$, $36,48,72,96$, and $120 \mathrm{~h}$, respectively ${ }^{7}$. Groups of starved L6 myoblasts were also treated with SB203580 $(10 \mu \mathrm{M}$, an inhibitor of p38MAPK), SP600125 (10 $\mu \mathrm{M}$, an inhibitor of SAPK/JNK), and LY294002 (10 $\mu \mathrm{M}$, an inhibitor of PI3 K) for 6 hours. After each experimental treatment, cells were lysed with an extraction buffer. To measure the phosphorylation of PKB/Akt, the samples were then homogenized in a sample buffer. The homogenate was centrifuged and the supernatant was collected. Proteins, 30-45 $\mu \mathrm{g} /$ lane, were separated on $12 \%$ polyacrylamide sodium dodecylsulfate gels and then transferred electrophoretically to a polyvinylidene fluoride membrane (Millipore; Bedford, MA, USA) ${ }^{1)}$. Anti-PKB/Akt antibody was purchased from Santa Cruz (Santa Cruz, CA, USA). SB203580, SP600125, and LY294002 were purchased from Tocris Bioscience (Bristol, UK). Antibody-specific bands were quantified using an image analyzer (BioRad). Data were expressed as the means \pm SEM. The statistical evaluation of data was performed using GraphPad prism (GraphPad Software, San Diego, CA, USA), and Student's t-test for group comparisons and ANOVA for multiple comparisons. A p value of $<$ 0.05 was considered statistically significant. The protocol for the study was approved by the Committee of Ethics in Research of the University of Yongin, in accordance with the terms of Resolution 5-1-20, December 2006.

\section{RESULTS}

The phosphorylation of PKB/Akt was significantly lower in L6 myoblasts grown under starvation conditions with low glucose and $0 \%$ FBS than that in the control group cul- tured with high glucose and 10\% FBS ( $\mathrm{n}=4$; Table 1, Fig. 1A). Serum-free starvation with low glucose for $6,12,24$, $36,48,72,96$, and 120 hours significantly decreased the phosphorylation of PKB/Akt ( $n=5$; Table 1, Fig. 1B). Furthermore, the decrease of $\mathrm{PKB} / \mathrm{Akt}$ phosphorylation in serum-free starvation with low glucose was partially restored by $10 \mu \mathrm{M}$ SP600125, an inhibitor of SAPK/JNK ( $\mathrm{n}=4$; Table 1, Fig. 1C). However, the starvation did not influence the abundance of PKB/Akt expression in any group $(n=4-5$; Table 1, Fig. 1A, 1B, and 1C).

\section{DISCUSSION}

Maintenance of muscle mass and of muscle function are important for healthy life, and is important in the rehabilitation of musculoskeletal disease in the field of physical therapy ${ }^{1,7,13,14)}$. The maintenance mechanisms of muscle mass include anabolic and catabolic signal transductions via $\mathrm{PKB} / \mathrm{Akt}$, a protein with a critical role ${ }^{1,5,10,11)}$. $\mathrm{PKB} / \mathrm{Akt}$ intermediates the signaling pathways that regulate cellular processes controlling growth, proliferation, and differentiation $^{2,3,11,12)}$, and supplementation with growth factors and nutrients increases the activity of $\mathrm{PKB} / \mathrm{Akt}^{10-12)}$. Supplementation encompasses intake of food, quality of diet, and the ability to optimally use ingested nutrients in the maintenance of muscle mass ${ }^{15,16)}$. In contrast, as muscle mass decreases, there is an accompanying loss in muscle strength and use of the nutrients that contributes to reduced muscle function and quality of activities of daily living (ADL). Malnutrition and chronic diseases such as diabetes mellitus, heart failure, and chronic obstructive pulmonary disease are also directly associated with a dramatic reduction in the phosphorylation of PKB/Akt with decrease of muscle mass ${ }^{15,17,18)}$. Our previous study reported that increases in atrophy markers and a decrease in PKB/Akt phosphorylation occur in gastrocnemius muscle strips atrophied by cast-immobilization, and $\mathrm{PKB} / \mathrm{Akt}$ phosphorylation is involved in the development of serum-free starvation-induced MuRF-1 expression in L6 myoblasts ${ }^{1,7)}$. Extracellular sig- 
A.

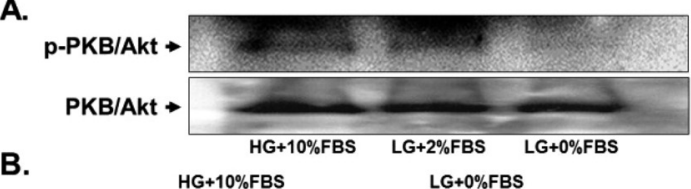

B.

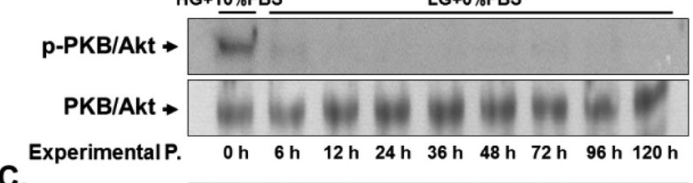

C.

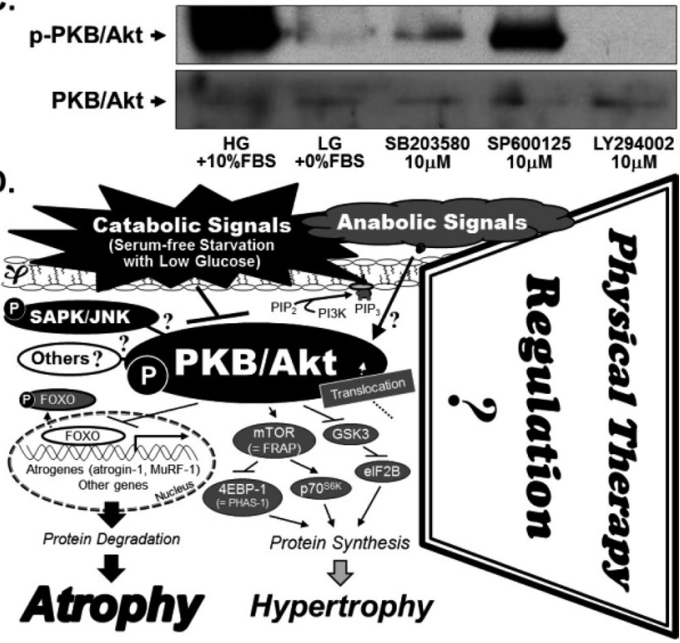

Fig. 1. Change of phosphorylation of PKB/Akt and a schematic representation of the cellular response induced by serumfree starvation with low glucose in L6 myoblasts $\mathrm{PKB} / \mathrm{Akt}$, protein kinase B/Akt; FBS, fetal bovine serum; h, hours; Experimental P, experimental period; HG, glucose of high concentration; LG, glucose of low concentration; SAPK/JNK, stress-activated protein kinase/c-Jun $\mathrm{NH}_{2}$-terminal kinase; SB203580, an inhibitor of p38MAPK; SP600125, an inhibitor of SAPK/JNK; LY294002, an inhibitor of phosphatidylinositol 3-kinase; MuRF-1, muscle specific RING finger-1; FOXO, Forkhead box $\mathrm{O}$ transcription factors; mTOR, mammalian target of rapamycin; FRAP, FKBP12-rapamycin-associated protein; GSK3, glycogen-synthase kinase 3; PI3K, phosphatidylinositol 3-kinase; $\mathrm{PIP}_{2}$, phosphatidylinositol (4,5)-bisphosphate $\left[\operatorname{Ptd} I n s(4,5) \mathrm{P}_{2}\right] ; \mathrm{PIP}_{3}$, phosphatidylinositol $(3,4,5)$-triphosphate $\left[\mathrm{Ptd} \operatorname{Ins}(3,4,5) \mathrm{P}_{3}\right] ; \mathrm{p}-\mathrm{PKB} /$ Akt, phosphorylated PKB/Akt; 4EBP-1, 4E-binding protein 1; PHAS-1, phosphorylated heat- and acid-stable protein 1; eIF2B, eukaryotic initiation factor $2 \mathrm{~B}$; $\mathrm{p} 70^{\mathrm{S} 6 \mathrm{~K}}$, p70 S6 kinase

nal-regulated kinase 1/2 (ERK1/2), stress-activated protein kinase/c-Jun $\mathrm{NH}_{2}$-terminal kinase (SAPK/JNK), and p38 mitogen-activated protein kinase (p38MAPK) are concurrently involved in atrophy induced by cast-immobilization and the starvation of skeletal muscle cells ${ }^{1,7)}$. Furthermore, our previous report demonstrated that cast-immobilization of rat gastrocnemius muscles increases the expression of muscle myoglobin ${ }^{19}$ ). It has recently been reported that cofilin in eukaryotic cells binds to actin and plays a role in actin dynamics and reorganization in cast immobilization- and starvation-induced atrophy in rat gastrocnemius muscles and L6 myoblasts ${ }^{20-22)}$. However, further systematic and scientific studies in the fields of electrotherapy, neurotherapy, hydrotherapy and others are needed to confirm the mechanisms of PKB/Akt in atrophied muscle strips and cells ${ }^{23-27)}$ (Fig. 1D). In summary, the phosphorylation of PKB/Akt decreased in starved L6 skeletal muscle cells. The present results suggest that serum-free starvation-induced atrophy is partially mediated by $\mathrm{PKB} / \mathrm{Akt}$ via the SAPK/ JNK pathway in L6 myoblasts.

\section{REFERENCES}

1) Kim J, Kim B: Differential regulation of MAPK isoforms during castimmobilization induced atrophy in rat gastrocnemius muscle. J Phys Ther Sci, 2010, 22: 217-222. [CrossRef]

2) Kops GJ, Burgering BM: Forkhead transcription factors are targets of signalling by the proto-oncogene PKB (C-AKT). J Anat, 2000, 197: 571-574. [Medline] [CrossRef]

3) Esposito F, Chirico G, Montesano Gesualdi N, et al.: Protein kinase B activation by reactive oxygen species is independent of tyrosine kinase receptor phosphorylation and requires SRC activity. J Biol Chem, 2003, 278: 20828-20834. [Medline] [CrossRef]

4) Tian B, Liu J, Bitterman P, et al.: Angiotensin II modulates nitric oxideinduced cardiac fibroblast apoptosis by activation of AKT/PKB. Am J Physiol Heart Circ Physiol, 2003, 285: H1105-H1112. [Medline]

5) von Maltzahn J, Bentzinger CF, Rudnicki MA: Wnt7a-Fzd7 signalling directly activates the Akt/mTOR anabolic growth pathway in skeletal muscle. Nat Cell Biol, 2012, 14: 186-191. [Medline] [CrossRef]

6) Bodine SC, Latres E, Baumhueter S, et al.: Identification of ubiquitin ligases required for skeletal muscle atrophy. Science, 2001, 294: 1704-1708. [Medline] [CrossRef]

7) Kim J, Won KJ, Lee HM, et al.: p38 MAPK participates in muscle-specific RING finger 1-mediated atrophy in cast-immobilized rat gastrocnemius muscle. Korean J Physiol Pharmacol, 2009, 13: 491-496. [Medline] [CrossRef]

8) Sandri M, Sandri C, Gilbert A, et al.: Foxo transcription factors induce the atrophy-related ubiquitin ligase atrogin-1 and cause skeletal muscle atrophy. Cell, 2004, 117: 399-412. [Medline] [CrossRef]

9) Stevenson EJ, Koncarevic A, Giresi PG, et al.: Transcriptional profile of a myotube starvation model of atrophy. J Appl Physiol 1985, 2005, 98: 1396-1406. [Medline] [CrossRef]

10) Kuzman JA, Gerdes AM, Kobayashi S, et al.: Thyroid hormone activates Akt and prevents serum starvation-induced cell death in neonatal rat cardiomyocytes. J Mol Cell Cardiol, 2005, 39: 841-844. [Medline] [CrossRef]

11) Stitt TN, Drujan D, Clarke BA, et al.: The IGF-1/PI3K/Akt pathway prevents expression of muscle atrophy-induced ubiquitin ligases by inhibiting FOXO transcription factors. Mol Cell, 2004, 14: 395-403. [Medline] [CrossRef]

12) Latres E, Amini AR, Amini AA, et al.: Insulin-like growth factor-1 (IGF1) inversely regulates atrophy-induced genes via the phosphatidylinositol 3-kinase/Akt/mammalian target of rapamycin (PI3K/Akt/mTOR) pathway. J Biol Chem, 2005, 280: 2737-2744. [Medline] [CrossRef]

13) Kim MY, Kim JH, Kim B, et al.: Comparison study on the daily performance capability and body fat percentage for a healthy life among elderly people using a senior welfare center. Toxicol Environ Health Sci, 2011, 3: 120-128. [CrossRef]

14) Kim JH, Kim MY, Kim B, et al.: A study on relationship between the participation in senior welfare programs and the recognition of health condition. Toxicol Environ Health Sci, 2012, 4: 92-99. [CrossRef]

15) Lima CR, Vasconcelos CF, Costa-Silva JH, et al.: Anti-diabetic activity of extract from Persea americana Mill. leaf via the activation of protein kinase B (PKB/Akt) in streptozotocin-induced diabetic rats. J Ethnopharmacol, 2012, 141: 517-525. [Medline] [CrossRef]

16) Vasconcelos CF, Maranhão HM, Batista TM, et al.: Hypoglycaemic activity and molecular mechanisms of Caesalpinia ferrea Martius bark extract on streptozotocin-induced diabetes in Wistar rats. J Ethnopharmacol, 2011, 137: 1533-1541. [Medline] [CrossRef]

17) Kapustian L, Kroupskaya I, Rozhko O, et al.: Akt1 expression and activity at different stages in experimental heart failure. Pathophysiology, 2014, 21: 147-151. [Medline] [CrossRef]

18) Kim SY, Lee JH, Huh JW, et al.: Cigarette smoke induces Akt protein degradation by the ubiquitin-proteasome system. J Biol Chem, 2011, 286: 
31932-31943. [Medline] [CrossRef]

19) Lee JU, Kim JH, Kim MY, et al.: Increase of myoglobin in rat gastrocnemius muscles with immobilization-induced atrophy. J Phys Ther Sci, 2013, 25: 1617-1620. [Medline] [CrossRef]

20) Kim MY, Kim JH, Lee JU, et al.: Decrease of both cofilin and LIM kinase phosphorylation in the skeletal muscles of immobilization-induced atrophy rats. J Phys Ther Sci, 2014, 26: 355-357. [Medline] [CrossRef]

21) Lee $\mathrm{CK}$, Park HJ, So $\mathrm{HH}$, et al.: Proteomic profiling and identification of cofilin responding to oxidative stress in vascular smooth muscle. Proteomics, 2006, 6: 6455-6475. [Medline] [CrossRef]

22) Kim MY, Lee JU, Kim JH, et al.: Cofilin phosphorylation decreased by serum-free starvation with low glucose in the L6 myoblasts. J Phys Ther Sci, 2014, 26: (in press).

23) Kim IH, Kim JH, Lee JU, et al.: The effect of an early lumbar exercise program on trunk strength and the Oswestry disability index after herniated nucleus pulposus surgery. J Phys Ther Sci, 2012, 24: 165-168. [CrossRef]
24) Kim JH, Choi YD, Kim MJ, et al.: Correlation between the changes in heat-induced digital infrared thermography imaging and body components in healthy volunteers. Toxicol Environ Health Sci, 2013, 5: 107-112. [CrossRef]

25) Kim JH, Lee LK, Lee JU, et al.: A pilot study on the effect of functional electrical stimulation of stroke patients in a sitting position on balance and activities of daily living. J Phys Ther Sci, 2013, 25: 1097-1101. [Medline] [CrossRef]

26) Kim JH, Kim IH, Lee JU, et al.: Change of muscular activity and dynamic stability of the knee joint due to excessive and repetitive jumping or cutting by female athletes. J Phys Ther Sci, 2012, 24: 715-719. [CrossRef]

27) Kim MY, Kim JH, Lee JU, et al.: The effect of low frequency repetitive transcranial magnetic stimulation combined with range of motion exercise on paretic hand function in female patients after stroke. Neurosci Med, 2013, 4: 77-83. [CrossRef] 